\title{
Refractory Atypical Teratoid/Rhabdoid Tumor
}

National Cancer Institute

\section{Source}

National Cancer Institute. Refractory Atypical Teratoid/Rhabdoid Tumor. NCI Thesaurus.

Code C162723.

An atypical teratoid/rhabdoid tumor that does not respond to treatment. 